\title{
SIGNIFIKANSI IMPLEMENTASI KONSEP EKONOMI ISLAM DALAM TRANSAKSI BISNIS DI ERA MODERN
}

\author{
Toha Andiko \\ Pascasarjana IAIN Bengkulu \\ Jl. Raden Fatah Pagar Dewa Bengkulu \\ Email: toha.andiko@gmail.com
}

\begin{abstract}
The thinking of Islamic economics in Indonesia today, is still limited to the theme of banking or financial institutions. The lack of development of Islamic economic concepts is still happening in terms of macro and microeconomics as well as systems in Islamic statistics and accounting. Implementation of Islamic economic system is expected to serve as a guide in state government, in building a prosperous society both materially and spiritually. In addition, Shariabased Islamic economics is expected to be a solution to economic underdevelopment, and to change the dominant capitalist and communist system over the years. Islamic economics is believed to save people morality from materialismhedonism, and can unite Muslims to jointly achieve falah (prosperity) in general. The significance of sharia-based Islamic economics is evident in the sharia bank's increasingly potential business offering services compared to conventional banks. Implementation of Islamic economics on muamalah activities can also be felt in the positive role of Islamic banks and non-bank syariah financial institutions that encourage the development of the real sector, this can be seen from the start of increasing the portion of the contract for the results of mudharabah and musyarakah and other transactions.
\end{abstract}

Keywords: Islamic economic, welfare, business transactions, modern era

\begin{abstract}
Abstrak: Pemikiran ekonomi Islam di Indonesia saat ini, masih sebatas tema perbankan atau lembaga keuangan saja. Kurangnya pengembangan konsep ekonomi Islam ini masih terjadi dalam hal ekonomi makro dan mikro serta sistem dalam statistik dan akuntansi Islam. Penerapan sistem ekonomi Islam diharapkan dapat dijadikan sebagai pedoman dalam pemerintahan bernegara, dalam membangun masyarakat yang sejahtera baik secara material dan spiritual. Selain itu, ekonomi Islam yang berbasis syariah diharapkan menjadi solusi terhadap keterbelakangan ekonomi, dan mengubah sistem kapitalis dan komunis yang mendominasi selama ini. Ekonomi Islam diyakini dapat menyelamatkan moral umat dari paham materialisme-hedonisme, serta dapat mempersatukan umat Islam untuk bersama-sama mencapai falah (kesejahteraan) secara umum. Signifikansi ekonomi Islam yang berlandaskan syariah tampak pada usaha bank syariah yang semakin lebih banyak memiliki potensi penawaran jasa dibandingkan bank konvensional. Implementasi ekonomi Islam pada kegiatan muamalah juga dapat dirasakan pada peran positif bank syariah dan lembaga keuangan syariah non bank yang mendorong berkembangnya sektor riil, hal ini dapat dilihat dari mulai bertambahnya porsi akad bagi hasil mudharabah dan musyarakah serta akad-akad lainnya.
\end{abstract}

Kata kunci: ekonomi Islam, falah, transaksi bisnis, era modern

\section{Pendahuluan}

Ekonomi Islam adalah termasuk ilmu pengetahuan sosial yang mempelajari perilaku ekonomi di masyarakat, yang diatur berdasarkan hukum Islam dan sesuai dengan dasar agama yaitu tauhid, rukun iman dan rukun Islam. Semakna dengan maksud di atas, ada juga yang menggunakan istilah Ekonomi Syariah, sebagai ilmu yang mempelajari permasalahan ekonomi sosial masyarakat yang diilhami oleh nilai-nilai Islam ${ }^{1}$.

Di dalam ajaran Islam, bekerja mencari nafkah atau melakukan kegiatan ekonomi merupakan kewajiban yang diperintahkan oleh Allah Swt, karena tidak ada sesuatu yang bisa didapat langsung tanpa harus melakukan

\footnotetext{
${ }^{1}$ Mardani,. Hukum Ekonomi Syariah di Indonesia, (Bandung: PT Refika Aditama, 2011), h.. 15
} 
kegiatan, hal ini senada dengan firman Allah dalam surat al-Taubah ayat 105:

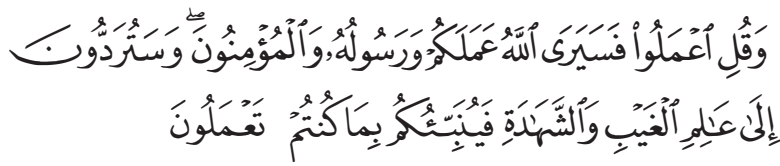

"Dan katakanlah: "Bekerjalah kamu, maka Allah dan Rasul-Nya serta orang-orang mumin akan melihat pekerjaanmu itu, dan kamu akan dikembalikan kepada [Allab] Yang Mengetahui akan yang ghaib dan yang nyata, lalu diberitakan-Nya kepada kamu apa yang telah kamu kerjakan". (AlTaubah: 105)

Penegasan dalam Alquran agar manusia bekerja adalah untuk menjadikan perekonomian semakin membaik dan sejahtera, serta pelarangan untuk menzalimi kepentingan orang lain atau mengambil harta orang lain secara paksa dan jalan pintas untuk menjadi kaya. Karena, dengan bekerja maka Allah akan memberikan pengampunan kepada hambanya, hal ini sebagaimana yang disabdakan oleh Rasulullah Muhammad saw: Siapa di waktu sorenya kelelahan karena kerja tangannya, maka di waktu sore itu ia mendapat ampunan. (HR. Thabrani dan Baihaqi).

Dari penggalan ayat Alquran dan hadis di atas dapat dicermati bahwa manusia haruslah berusaha guna memenuhi kebutuhan hidupnya dengan cara bekerja sesuai dengan ruang lingkup syariah, atau melakukan pekerjaan yang sesuai dengan aturan Islam.

\section{Pengertian Ekonomi Islam dan Ruang Lingkupnya 1. Pengertian Ekonomi Islam}

Pengertian apa dan bagaimana ekonomi Islam saat ini masih banyak diperdebatkan, sehingga ada yang membagi mazhab ekonomi Islam menjadi tiga yaitu; mazhab Baqir al-Sadr, mazhab mainstream, dan mazhab alternatif-kritis. Namun, pengembangan dari ketiga mazhab ini belum begitu gencar dan masih dalam tatanan konsep dasar, kecuali mazhab mainstream² ${ }^{2}$.

\footnotetext{
${ }^{2}$ Adiwarman Karim, "Ekonomi Islam: Suatu Kajian Ekonomi Makro", (Jakarta: the International institute of Islamic Thought Indonesia, 2002), h. 195-197
}

Perdebatan terkait bagaimana ekonomi Islam terus menuai perhatian, ada yang berpendapat bahwa ekonomi Islam pada dasarnya adalah sama dengan ekonomi konvensional hanya saja ditambah dengan Islam, ada pula yang mengatakan bahwa ekonomi Islam adalah ekonomi yang sama sekali tidak berbeda dengan ekonomi lainnya, dengan minus kapitalis dan sosialis, serta penambahan Islam. Pendapat yang lainnya mengatakan bahwa ekonomi Islam lebih banyak mengadopsi dari sistem ekonomi yang sudah ada, dengan mengungkapkan kelemahan sistem lain guna menunjukkan bahwa ekonomi Islam secara substansial adalah yang lebih baik. Meskipun demikian, semua lontaran kritikan dari para ahli ekonomi tersebut bertujuan untuk menuntut para pendukung ekonomi Islam agar mampu untuk memberikan jawaban serius terkait dengan konsep ekonomi Islam.

Para ahli mencoba mendefinisikan ekonomi Islam atau ekonomi syariah dengan beberapa variasi. Zainuddin Ali menyatakan bahwa ekonomi syariah merupakan kumpulan norma hukum yang disandarkan pada Alquran dan hadis untuk mengatur perekonomian di tengah masyarakat ${ }^{3}$. Menurut Mardani, ekonomi Islam ialah suatu usaha atau kegiatan ekonomi yang dilakukan perorang, atau perkelompok, atau badan usaha yang berbentuk hukum maupun non-berbentuk hokum, dengan tujuan komersial dan tidak komersial serta dilakukan sesuai dengan tatanan ajaran agama Islam ${ }^{4}$. Hasanuzzaman mengatakan bahwa ekonomi Islam adalah ilmu dan aplikasi petunjuk dan aturan syariah yang mencegah ketidak adilan dalam memperoleh dan menggunakan sumberdaya material agar memenuhi kebutuhan manusia, dan agar dapat menjalankan kewajibannya kepada Allah dan masyarakat.

Sedangkan Khurshid Ahmad menjelaskan bahwa ekonomi Islam adalah suatu upaya sistematik untuk memahami masalah ekonomi dan perilaku manusia yang berkaitan dengan

\footnotetext{
${ }^{3}$ Mardani, Hukum Ekonomi Syariah di Indonesia..., h. 20

${ }^{4}$ Mardani, Hukum Ekonomi Syariah..., h. 20
} 
masalah itu dari perspektif Islam. Nejatuallah Siddiqi menyatakan bahwa ekonomi Islam adalah tanggapan pemikir-pemikir muslim terhadap tantangan ekonomi pada zamannya. Dimana dalam upaya ini mereka dibantu oleh Alquran dan Sunah disertai dengan argumentasi dan pengalaman empirik. Menurut Akram Khan bahwa ekonomi Islam adalah suatu upaya yang memusatkan perhatian pada studi tentang kesejahteraan manusia yang dicapai dengan mengorganisir sumber daya di bumi atas dasar kerjasama dan partisipasi. Adapun Umar Chapra menyatakan bahwa ekonomi Islam adalah cabang ilmu yang membantu merealisasikan kesejahteraan manusia melalui alokasi dan distribusi sumberdaya yang langka yang sejalan dengan syariah Islam tanpa membatasi kreativitas individu ataupun menciptakan suatu ketidakseimbangan ekonomi makro atau ekologis 5 .

Dari berbagai definisi dari para ahli ekonomi syariah di atas, dapat diketahui bahwa unsur penting yang menjadi rujukan dalam setiap kegiatan ekonomi Islam adalah bersumber dari wahyu Ilahi dan hadis. Sumber utama tersebut kemudian diinterpretasikan melalui ijtihad dan menggunakan cara pengambilan dalil lainnya, yang secara nyata dan tidak nyata langsung berkaitan dengan sumber utamanya yaitu kalamullah dan Sunah Rasulullah Muhammad saw.

Pada dasarnya, ilmu ekonomi Islam tidak jauh berbeda dengan ilmu ekonomi yang ada, karena sama-sama mempelajari perilaku masyarakat dalam kegiatan ekonomi berupa produksi, distribusi, dan konsumsi serta pemilihan sumberdaya yang bersifat langka, lalu mengalokasikan sumberdaya tersebut guna memenuhi kebutuhan manusia. Namun, dalam Islam semua kegiatan tersebut juga dilandaskan dengan iman kepada Allah, karena setiap kegiatan perekonomian tersebut merupakan

${ }^{5}$ M. Umer Chapra,, "Masa Depan Ilmu Ekonomi Sebuah Tinjauan Islam" (terjemahan dari: The Future of Economics: An Islamic Perspective), (Jakarta: Gema Insani Press, 2001), hal. 87 ibadah dan penghambaan manusia kepada Penciptanya. Ilmu ekonomi Islam tidak hanya memperhatikan aspek komersial yang didapat oleh manusia, namun juga pembentukan sistem dalam perilaku kehidupan ekonomi yang sesuai dengan tatanan syariat Islam.

Ada pula yang menafsirkan bahwa ekonomi Islam adalah sistem yang menyangkut pengaturan kegiatan ekonomi dalam suatu pemerintahan atau masyarakat dengan menggunakan metode tertentu. Misalnya, bank Islam dapat disebut sebagai salah satu unit dari beroperasinya suatu sistem ekonomi Islam, yang berada dalam ruang lingkup makro maupun mikro, yang mendoktrin pelarangan riba dan memiliki karakteristik sistem bagi hasil sebagai jalan keluar dari permasalahan krisis ekonomi. Selain itu, ada juga yang mendefinisikan ekonomi Islam sebagai perekonomian yang ada di dunia Islam atau hanya untuk umat Islam saja. Sehingga, yang dipelajari ialah bagaimana perekonomian yang terjadi di masamasa Islam mulai masuk di Arab yaitu pada zaman rasulullah, sahabat, tabiin hingga pada zaman sekarang, lalu bagaimana implementasi perekonomian Islam di negara-negara Muslim seperti Arab Saudi, Mesir, Qatar, Irak, Iran, Malaysia, Indonesia dan sebagainya.

Pemikiran ekonomi Islam di Indonesia khususnya saat ini, masih sebatas tema perbankan atau lembaga keuangan saja. Sehingga gagasan bank Islam terlebih dahulu yang berkembang dalam upaya penerapan prinsip ekonomi Islam. Kurangnya pengembangan konsep ekonomi Islam ini masih dirasakan dalam hal ekonomi makro dan mikro serta sistem dalam statistik dan akuntansi Islam, ini karena kurangnya kreatifitas pengembangan dalam tatanan ilmu sosial tersebut. Pembahasan yang komprehensif tentang konsep ekonomi Islam sangat perlu, guna menjawab kritikan dari para ekonom konvensional, terkait dengan eksistensi ekonomi Islam sebagai solusi dalam memecahkan persoalan yang terjadi pada masalah ekonomi di seluruh belahan dunia. 


\section{Ruang Lingkup Ekonomi Islam}

Tidak jauh berbeda dengan defenisi ekonomi Islam, masih terdapat juga perdebatan terkait dengan ruang lingkup ekonomi Islam oleh beberapa ekonom. Sebagian ahli menegaskan bahwa ruang lingkup dari ekonomi Islam adalah peraturan perekonomian masyarakat muslim dan negara muslim itu sendiri, namun hal ini masih sangat sempit. Padahal, ekonomi Islam seharusnya dapat dijadikan sebagai pedoman bagi negara lain yang ingin mengadopsi sistem ekonomi ini dalam tatanan negara mereka. Selain itu, ruang lingkup ekonomi Islam yang masih terbatas, tampaknya menjadi administrasi kekurangan sumber-sumber daya manusia dipandang dari konsepsi etik kesejahteraan dalam Islam. Oleh sebab itu, ekonomi Islam tidak hanya mengenai sebab-sebab material kesejahteraan, tetapi juga mengenai hal-hal non material yang tunduk kepada larangan Islam tentang konsumsi dan produksi. Hal ini menunjukkan bahwa pengembangan ekonomi Islam masih minim dan menuai banyak perdebatan, ini disebabkan oleh konsep ekonomi Islam yang belum banyak berkembang sehingga memunculkan banyak kritikan dari para ekonom.

Untuk mengetahui ruang lingkup dari ekonomi Islam ini, maka perlu untuk mempelajari terlebih dahulu cakupan bab dan pasal dalam kompilasi hukum ekonomi syariah, yang memuat tentang berbagai aturan terkait dengan muamalah ekonomi yaitu perdagangan, etik, lembaga keuangan, produksi dan distribusi, akuntansi dan kesejahteraan sosial. Untuk lebih jelasnya, maka ruang lingkup ekonomi syariah meliputi aspek ekonomi yaitut; $b a ̈ i$, akad-akad jual beli, syirkah, mudharabah, murabahah, muzara'ah dan musaqah, khiyar, istisna, ijarah, kafalah, hawalah, rahn, wadiah, gashb dan itlaf, wakalah, shulhu, pelepasan hak, tamin, obligasi, syariah mudharabah, pasar modal, reksadana syariah, sertifikasi bank Indonesia syariah, pembiayaan multi jasa, qardh, pembiayaan rekening koran syariah, dana pensiun syariah, zakat dan hibah, dan akuntansi syariah. Untuk lebih jelasnya, ruang lingkup ekonomi Islam dapat dijelaskan dalam tabel berikut di bawah ini:
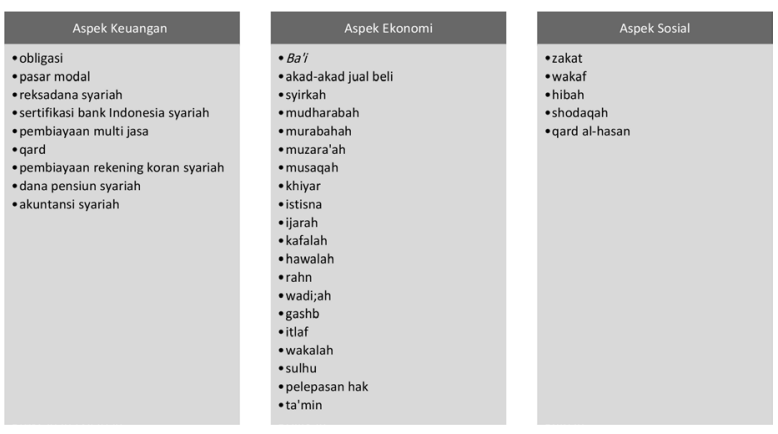

Sebagai perbandingan, dapat dirujuk dari Undang-undang Peradilan Agama No. 7 Tahun 1989, maka dapat diketahui bahwa ruang lingkup ekonomi syariah meliputi: bank syariah, asuransi syariah, lembaga keuangan mikro syariah, reasuransi syariah, obligasi syariah, surat berjangka menengah syariah, reksadana syariah, sekuritas syariah, pegadaian syariah, pembiayaan syariah, dana pensiun lembaga keuangan syariah dan bisnis syariah.

Dari pemaparan di atas, maka jelas bahwa ekonomi Islam mempelajari seluruh perilaku kegiatan ekonomi yang bersifat makro dan mikro dari mulai jual-beli, peraturan perdagangan, perkongsian dalam usaha, asumsi rasionalitas konsumen, akad-akad dalam perdagangan, investasi syariah, produksi dan distribusi, akuntansi, manajemen, serta aturan dan pengawasan dalam lembaga keuangan syariah.

\section{Sumber Hukum Ekonomi Islam}

Setiap menentukan sesuatu, seseorang seringkali memiliki pandangan yang berbedabeda, hal ini tentunya memberikan hasil yang berbeda pula. Faktor yang mempengaruhi pandangan tersebut berasal dari berbagai pemikiran, keyakinan, maupun tujuan. Islam menentukan pandangannya sesuai dengan Alquran. Menurut keyakinan seseorang yang beragama Islam, maka penetapan hukum yang telah ditentukan haruslah sesuai dengan ajaran Alquran, karena inilah yang terbaik dan tentu akan memberikan keberkahan dan kesejahteraan bagi umat. Namun, setiap ulama memiliki sudut pandang yang berbeda-beda sesuai dengan disiplin ilmu dan fokus kecendrungannya, 
sehingga setiap hasil keputusan dalam hukum Islam juga berbeda antara pendapat ulama yang satu dengan yang lainnya.

Dalam mengambil istinbath hukum ekonomi Islam, sumber-sumber hukum ekonomi Islam sangat esensial bagi para ulama guna melakukan ijtihad untuk menentukan manhaj yang berbedabeda. Meskipun perbedaan pemikiran tetap ada di kalangan para ulama, namun asas dari setiap penentuan hukum tersebut bersumber pada dua hal yaitu Alquran dan hadis. Berikut adalah sumber-sumber hukum ekonomi Islam ${ }^{6}$ :

\section{Alquran}

Alquran adalah sumber pertama dan utama bagi ekonomi Islam, di dalamnya dapat ditemui hal-hal yang berkaitan dengan ekonomi dan juga terhadap hokum-hukum dan undangundang ekonomi dalam tujuan Islam, di antaranya seperti hukum diharamkannya riba, dan diperbolehkannya jual beli yang tertera pada surat Al-Baqarah[2] ayat 275:

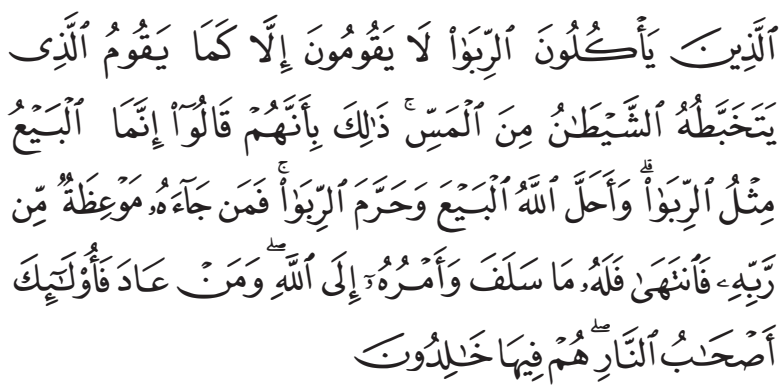

"Orang-orang yang makan [mengambil] riba tidak dapat berdiri melainkan seperti berdirinya orang yang kemasukan syaitan lantaran [tekanan] penyakit gila. Keadaan mereka yang demikian itu, adalah disebabkan mereka berkata [berpendapat], sesungguhnya jual-beli itu sama dengan riba, padahal Allah telah menghalalkan jual-beli dan mengharamkan riba. Orang-orang yang telah sampai kepadanya larangan dari Tuhannya, lalu terus berhenti [darimengambilriba], maka baginya apa yang telah diambilnya dahulu [sebelum datang larangan]; dan urusannya [terserah] kepada Allah.

\footnotetext{
${ }^{6}$ Naqvi, Syed Nawab Haider, "Menggagas Ilmu Ekonomi Islam", terjemahan dari: Islam, Economics, and Society, (Yogyakarta: Pustaka Pelajar,.2003), h. 57
}

Orang yang mengulangi [mengambil riba], maka orang itu adalah penghuni-penghuni neraka; mereka kekal di dalamnya". (Al-Baqarah[2]: 275)

\section{Al-Sunnah al-Nabawiyah}

Al-Sunnah adalah sumber kedua dalam perundang-undangan Islam. Di dalamnya dapat dijumpai khazanah aturan perokonomian Islam. Di antaranya seperti sebab hadis yang isinya memerintahkan untuk menjaga dan melindungi harta, baik milik pribadi maupun umum serta tidak boleh mengambil harta yang bukan miliknya.

"Sesungguhnya (menumpahkan) darah kalian, (mengambil) harta kalian, (mengganggu) kehormatan kalian adalah haram sebagaimana haramnya hari kalian saat ini, di bulan ini, di negeri ini...."(H.R Bukhari)

Contoh lain misalnya Al-Sunnah juga menjelaskan jenis-jenis harta yang harus menjadi milik umum dan untuk kepentingan umum, tertera pada hadis: "Aku ikut berperang bersama Rasulullah, ada tiga hal yang aku dengar dari Rasulullah: Orang-orang muslim bersyarikat (sama-sama memiliki) tempat penggembala, air dan api” (HR. Abu Dawud)

\section{Ijtihad Ulama}

Istilah ijtihad adalah mencurahkan daya kemampuan untuk menghasilkan hukum syara' dari dalil-dalil syara' secara terperinci yang bersifat operasional, dengan cara mengambil kesimpulan hukum (istimbat). Al-Amidi menjelaskan bahwa untuk melakukan ijtihad, seseorang harus sampai merasa tidak mampu untuk mencari tambahan kemampuan. Menurut Imam Al-Ghozali, batasan sampai merasa tidak mampu sebagai bagian dari definisi ijtihad sempurna (al ijtihad al-taam). Imam Syafi'i mengatakan bahwa seorang mujtahid tidak boleh mengatakan "tidak tahu" dalam suatu permasalahan sebelum ia berusaha dengan sungguh-sungguh untuk menelitinya, dan tidak boleh mengatakan "aku tahu" seraya menyebutkan hukum yang diketahui itu, sebelum 
ia mencurahkan kemampuan dan mendapatkan hukum itu. Keberadaan ijtihad sebagai sebuah hukum dinyatakan dalam Alquran pada surat al-Nisa [4] ayat 83:

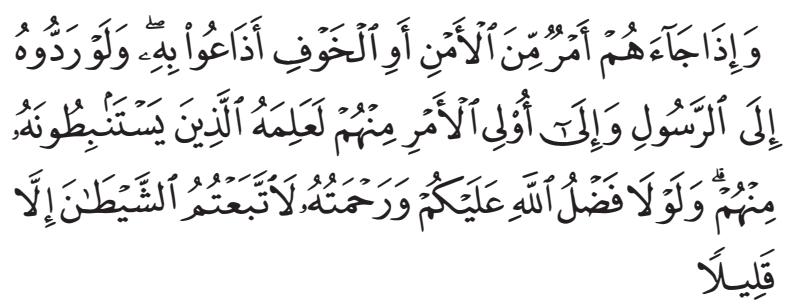

"Dan apabila datang kepada mereka suatu berita tentang keamanan ataupun ketakutan, mereka lalu menyiarkannya. dan kalau mereka menyerahkannya kepada Rasul dan ulil Amri di antara mereka, tentulah orang-orang yang ingin mengetahui kebenarannya (akan dapat) mengetahuinya dari mereka (Rasul dan ulil Amri). kalau tidaklah karena karunia dan rahmat Allah kepada kamu, tentulah kamu mengikut syaitan, kecuali sebahagian kecil saja (di antaramu)".

\section{Kitab-Kitab Fikih Umum dan Khusus}

Kitab-kitab ini menjelaskan tentang ibadah dan muamalah, di dalamnya terdapat pula bahasan tentang ekonomi yang kemudian dikenal dengan istilah al-Mu'amalah al-Maliyah, isinya merupakan hasil-hasil ijtihad ulama terutama dalam mengeluarkan hukum-hukum dari dalil-dalil Alquran maupun hadis yang sahih. Adapun bahasan-bahasan yang langsung berkaitan dengan ekonomi Islam adalah: zakat, sedekah sunah, fidyah, zakat fitrah, jual beli, riba dan jual beli uang, dan lainnya.

Dari keempat sumber hukum ekonomi Islam tersebut, maka dapatlah dipahami bahwa para ulama dalam memutuskan perkara terkait dengan perihal kegiatan ekonomi selalu mengutamakan semua sumber hukum tersebut. Selain itu, asas maslahah juga diutamakan dalam nilainilai ajaran Islam yaitu lebih mengutamakan kepentingan umum di atas kepentingan individu. Meskipun, ada beberapa ulama yang menggunakan asas illat dalam menentukan sebuah manhaj hukum, ini dilakukan dengan cara beralasan bahwa terdapat kepentingan lain yang lebih mendesak dan dampaknya akan memberikan kontribusi kepada hal yang lebih besar, meskipun harus melanggar penetapan dari hukum yang telah ada. Namun, semua ketetapan itu dilakukan berdasarkan atas tiga kebutuhan utama dalam kehidupan yaitu kebutuhan pokok (dharuriyah) dan kebutuhan sekunder (hajiyah) serta kebutuhan pelengkap atau (tahsiniyah). Maka dalam Islam, setiap hukum yang diambil haruslah berdasarkan dari salah satu tiga unsur kebutuhan manusia tersebut, dan kesemuanya terbukti bertujuan untuk mewujudkan kemasalahatan manusia di dunia maupun di akhirat.

Selain dari sumber-sumber hukum ekonomi Islam di atas, terdapat asas atau landasan hukum ekonomi Islam yang digunakan oleh para ulama dalam menerangkan penetapan hukum yang dilakukan. Setidaknya terdapat tiga hal yang menjadi asas para ulama dalam menentukan hukum ekonomi Islam, yaitu:

1. Asas pertukaran manfaat, melalui kerjasama dan saling memiliki.

Para ulama menggunakan dasar asas pertukaran manfaat, karena setiap norma hukum yang diciptakan untuk manusia adalah untuk kegunaan manusia itu sendiri, semua yang diciptakan di muka bumi saling memberikan manfaat. Maka, setiap individu memiliki tanggung jawab dalam memiliki apa yang telah Allah ciptakan, menjaganya dan melestarikan nya. Oleh sebab itu, dalam pertukaran manfaat, setiap tindakan ekonomi haruslah dapat saling menguntungkan, saling tolong dan tidak mendahulukan kepentingan perorangan. Sebagai contoh, perusahaan harus bertanggung jawab terhadap kelestarian alam dan harus memiliki rasa tanggung jawab terhadap ekologi, adanya rasa saling memiliki dan distribusi secara merata kepada seluruh manusia dari seluruh elemen masyarakat.

${ }^{7}$ Atang Abd Hakim, Fiqh Perbankan Syariah, (Bandung; Refika Aditama, 2011), h. 165 
2. Asas pemerataan kesempatan yang disertai kerelaan dan tidak ada penipuan atau spekulasi.

Asas pemerataan merupakan salah satu bentuk penerapan prinsip keadilan dalam teori hukum Islam. Setiap masyarakat dapat memiliki kesempatan yang sama dalam melakukan usaha ekonomi, tanpa adanya monopoli dan kapitalisme. Asas ini menentang keras penumpukan harta yang hanya ada pada orang kaya, maka setiap harta diwajibkan untuk diputar dalam usaha dan dilarang untuk ditimbun. Selain itu, Islam mewajibkan kepada para pemilik harta untuk mengeluarkan zakat, infaq dan sedekah kepada orang yang tidak mampu, sehingga dapat mengentaskan kemiskinan serta mengurangi pengangguran, dan disparitas sosial. Selain itu, rela sama rela menjadikan antara penjual dan pembeli saling suka, dan tidak ada rasa gundah di hati mereka dalam menerima dan menyerahkan harta dalam bentuk muamalah. Hal ini juga berguna untuk mewujudkan kejelasan dalam transaksi muamalah sehingga tidak terjadi gharar, yang berupa penipuan maupun spekulasi.

3. Asas kebaikan dan ketakwaan

Asas kebaikan dan ketakwaan merupakan totalitas dari semua asas muamalah lainnya, karena dalam melaksanakan kegiatan ekonomi haruslah dilandaskan dengan iman dan ditujukan untuk ibadah, kemudian baru disertakan untuk memenuhi kebutuhan diri sendiri dan orang lain. Asas ini menjadikan setiap manusia adalah sama, tidak ada perbedaan antara kaya dan miskin, ataupun golongan dan ras. Karena semuanya sama di mata Allah kecuali tingkat orang yang lebih baik (Muhsinin) dan lebih bertakwa (Muttaqin). Asas kebaikan dan ketakwaan ini juga merupakan pilar kegiatan dalam perbankan syariah, agar setiap usaha yang dilakukan adalah dalam rangka pemenuhan dan pelaksanaan saling membantu antara sesama manusia untuk meraih derajat takwa.

\section{Tujuan dan Fungsi Ekonomi Islam}

\section{Tujuan Ekonomi Islam}

Islam merupakan agama kasih sayang untuk seluruh penghuni alam semesta, dibawa oleh Rasulullah melalui petunjuk wahyu dari Allah Swt. Hukum yang ada dalam Islam tentunya sangat berbeda dengan hukum-hukum lain yang dibuat oleh tangan manusia. Karena tujuan utama dari ekonomi Islam ialah untuk mewujudkan kemasalahatan manusia di dunia maupun di akhirat, maka tujuan ekonomi Islam adalah selaras dengan tujuan dari Syariat Islam itu sendiri yaitu untuk mencapai kebahagiaan di dunia dan terbebaskan dari siksa api neraka di akhirat. Dengan cara menjalankan normanorma kehidupan yang baik dan terhormat (hayyah thayyibah), maka tujuan falah dapat tercapai yang meliputi aspek-aspek mikro dan makro serta melewati horizon waktu di dunia dan di akhirat ${ }^{8}$.

Penerapan sistem ekonomi Islam diharapkan dapat dijadikan sebagai pedoman dalam pemerintahan negara, dalam membangun masyarakat yang sejahtera baik secara material dan spiritual. Selain itu, ekonomi syariah diharapkan menjadi solusi terhadap keterbelakangan ekonomi pada negara-negara muslim, dan mengubah sistem kapitalis dan komunis yang selama ini dibawa oleh barat ke negara-negara tersebut. Ekonomi Islam diyakini dapat menyelamatkan moral umat dari paham materialisme-hedonisme, serta dapat mempersatukan umat Islam dalam satu panji Islam dan bersama-sama mencapai falah (kesejahteraan) secara umum.

Nilai-nilai yang ada dalam ekonomi Islam tidak hanya semata untuk kehidupan umat muslim saja, namun juga dapat berguna bagi seluruh umat lainnya di berbagai belahan negara, karena ekonomi Islam mempunyai tujuan untuk memberikan kebahagiaan di dunia dengan pendekatan agama. Pada dasarnya, setiap kegiatan bisnis di dalam Islam selalu

8 Pusat Pengkajian dan Pengembangan Ekonomi Islam (P3EI). 2012. Ekonomi Islam. Jakarta: PT Raja Grafindo Persada. Hal. 101 
dilandaskan pada prinsip-prinsip syariah yang bersumber dari Alquran, Sunah, Ijma' dan qiyas. Berdasarkan dari sumber literatur tersebut, maka dapat disimpulkan ada 7 tujuan dari ekonomi Islam yaitu:

1. Menyeimbangkan antara kehidupan dunia dan kehidupan akhirat.

Dalam aktivitas ekonomi, setiap manusia dituntut untuk memenuhi kebutuhan hidupnya agar dapat sejahtera. Tujuan dari melakukan kegiatan ekonomi tersebut adalah untuk mencapai kemakmuran hidup di dunia, namun dalam ekonomi Islam manusia juga dituntut untuk tidak melupakan kehidupan akhirat. Ini karena seorang muslim meyakini bahwa akan ada kehidupan yang kekal kelak di akhirat, dan derajat yang tinggi bagi kehidupan seorang hamba di akhirat nanti ialah mereka yang mampu meningkatkan ketaatannya kepada Allah yang telah menciptakan dirinya. Terkait hal ini, dalam kehidupan di dunia, terdapat tiga macam tipe manusia yaitu:

a. Manusia yang selalu mementingkan kehidupan duniawi, dan melalaikan ibadah kepada Allah, terlena dengan keadaan kekayaan yang terus bertambah, padahal harta tersebut merupakan cobaan bagi nya, sehingga ketika kerugian di alami nya, mulailah rasa insaf muncul dan mengingatkannya.

b. Orang yang selalu beribadah dan mengabdikan diri nya pada Allah dan yakin bahwa rezeki hanya datang dari Allah, namun mereka tidak bekerja untuk mencari nafkah. Tipe orang seperti ini juga dilarang dalam Islam, karena segala sesuatu yang berlebihan justru akan menjadi mudharat. Bagaimana pun kerja keras untuk mencapai harapan adalah bagian dari bentuk usaha serta diiringi dengan doa.

c. Tipe manusia yang taat beribadah dan juga selalu berusaha. Inilah golongan yang ingin dicetak oleh ekonomi Islam, yaitu mereka golongan yang melaksanakan aktivitas ekonomi tanpa mengabaikan nilai-nilai agama.

2. Mencapai distribusi pendapatan dan kekayaan yang adil dan merata.

Konsep dari ekonomi syariah ialah menciptkan keadilan bagi setiap umat manusia. Pada setiap aktivitas ekonomi antara bank dan nasabah mendapatkan laba atau keuntungan yang sama rata sehingga tidak adanya suatu diskriminasi. Hal ini, senada dengan apa yang tercantum dalam firman Allah pada Qs. Al-An'am ayat 165, Al-Nahl ayat 71, dan AlZukhruf ayat 32.

3. Menghindari kekacauan dan kerusuhan.

Pemerintah yang baik adalah pemerintah yang mendengarkan dan menerima nasihat dari rakyat nya, karena penguasa tersebut ada karena keberadaan rakyat, tanpa rakyat maka tak ada negara. Dalam mengelola perekonomian sesuai dengan syariat Islam, pemerintah dilarang berbuat semena-mena terhadap rakyat, karena akan mengakibatkan terjadi nya penindasan ekonomi di dalam nya. Misal, pengambilan perusahan swasta yang dimiliki oleh masyarakat secara paksa oleh pemerintah, karena perusahaan tersebut dapat memiliki potensi yang baik di masa depan, atau penindasan terhadap hak-hak rakyat dalam memberikan pendapat atau suara kepada para penguasa, namun justru dibalas dengan penculikan dan dijadikan terdakwa kasus serta dizalimi. Untuk itu, ekonomi syariah adalah membentuk suatu pemerintahan yang mampu mengatur perekonomian secara baik, benar, dan adil, dari berbagai bidang, agar semua masyarakat dapat merasakan keadilan, kesejahteraan dan kemakmuran dimanapun mereka berada.

4. Menciptakan kebebasan individu dalam hal kesejahteraan sosial.

Setiap individu diberikan kebebasan untuk melakukan aktivitas ekonomi, dalam konsep ekonomi syariah tidak pernah memaksa individu, sebagaimana sesuai dalam ayat 
Al-qur'an surah Ar-Ra'du ayat 36 dan surah Lukman ayat 22.

5. Menempatkan ibadah kepada Allah lebih dari segalanya.

Tujuan utama dalam konsep ekonomi ialah untuk mencari ridho Allah SWT bukan semata-mata untuk mencari keuntungan materil. Melakukan aktivitas perekonomian diniatkan ibadah akan mendapatkan hasil yang lebih dibandingkan niat untuk mendapatkan harta. Dengan diniatkan untuk beribadah maka kita akan mendapatkan dua hal sekaligus yaitu pahala dan harta.

6. Meraih tujuan perekonomian yang diperintahkan Allah Swt.

Kegiatan ekonomi menurut ajaran islam adalah suatu aktivitas atau kegiatan yang mampu memberikan dampak baik terhadap semua masyarakat. Diharapkan dengan adanya konsep ekonomi syariah ini, mampu memberikan kesejateraan dan kemaslahatan bagi seluruh umat manusia.

7. Membentuk masyarakat dengan norma sosial yang kokoh yang menjunjung tinggi rasa persaudaraan dan keadilan yang universal.

Salah satu tujuan dalam ekonomi Islam ialah membentuk pribadi masyarakat yang tidak egois, terutama dalam hal bermasyarakat. Islam mengajarkan manusia untuk hidup bersosial saling menyayangi, rasa tolongmenolong dan menghilangkan sifat dengki, takabur, riya' dan memementingkan kepentingan pribadi atau golongan. Tidak ada perbedaan ras, strata sosial dalam Islam, semua orang memiliki hak yang sama dalam melakukan kegiatan ekonomi, inilah yang membedakan ekonomi Islam dengan ekonomi buatan manusia, karena Islam mendukung keadilan dalam bisnis dan diaplikasikan dalam perbuatan.

Menurut pendapat Muhammad Abu Zahrah sebagaimana yang dikutip oleh Rahman mengatakan bahwa terdapat tiga sasaran hukum Islam yang mana dapat memberikan pandangan bahwa Islam adalah agama yang diturunkan untuk rahmat bagi semesta alam, dan memberikan kontribusi dalam menjaga keadilan dan kesejahteraan kehidupan bermasyarakat, adapun ketiga sasaran tersebut adalah sebagai berikut':

1. Penyucian jiwa agar setiap muslim bisa menjadi sumber kebaikan bagi masyarakat dan lingkungannya.

2. Tegaknya keadilan dalam masyarakat. Keadilan yang dimaksud mencakup aspek kehidupan di bidang hukum dan muamalah.

3. Tercapainya maslahah (merupakan puncaknya). Para ulama menyepakati bahwa maslahah yang menjadi puncak sasaran di atas mencakup lima jaminan dasar, yaitu: keselamatan keyakinan agama (al-din), kesalamatan jiwa (al-nafs), keselamatan akal (al-aql), keselamatan keluarga dan keturunan (al-nasl) dan keselamatan harta benda (al mal).

Dengan demikian, dapat disimpulkan bahwa ekonomi Islam sekaligus merupakan jawaban terhadap persoalan-persoalan sosial yang terjadi di masyarakat, setiap kegiatan ekonomi Islam bahkan sangat mungkin beradaptasi dengan perubahan-perubahan sosial, adaptasi yang dilakukan tetap berlandaskan pada prinsip syariat Islam yang kokoh dan bersifat universal. Ini juga membuktikan bahwa Islam adalah agama yang selalu dapat mengikuti perubahan zaman dan sesuai pada setiap tempat.

\section{Fungsi Ekonomi Islam}

Manusia sebagai khalifah di muka bumi diberikan oleh Allah hak untuk mengurus dan mengatur tatanan hidup dan kehidupan, termasuk dalam mengatur ekonomi di dunia, agar kehidupan dalam bermasyarakat menjadi sejahtera dan dapat memenuhi kebutuhan produksi dan konsumsi. Ekonomi Islam befungsi sebagai pemberi jalan atau pedoman untuk semua manusia agar dapat mencapai tujuan di dunia dan di akhirat dan tidak sesat. Dengan kata lain, Ekonomi Islam juga membawa kehidupan

\footnotetext{
${ }^{9}$ Afzalur Rahman. 1995. Doktrin Ekonomi Islam Jilid I. Yogyakarta: Dana Bhakti Wakaf. Hal. 45
} 
manusia agar dapat hidup lebih teratur, tertib dan tentram tanpa merugikan orang lain serta menjalin hubungan baik dengan pencipta hablum minallah, hubungan baik dengan sesama manusia hablum minannas, serta hubungan dengan alam lingkungan hablum minal alam. Maka, ekonomi Islam sangat mendukung tiga hal prinsip utama yaitu:

a. Place (lingkungan/tempat), artinya manusia harus menjaga kelestarian lingkungan, setiap kegiatan ekonomi yang dilakukan tidak boleh mengakibatkan kerusakan alam, serta merugikan orang lain dan generasi selanjutnya. Hal ini bertentangan dengan ekonomi konvensional yang membolehkan denda terhadap para pencemar alam, kebalikan dari itu ekonomi Islam justru lebih mengutamakan tindakan preventif atau mencegah kerusakan dari pada membiarkan usaha yang mencemari lingkungan tersebut dan dapat mengakibatkan resiko yang lebih besar, seperti banjir, keracunan, muncul nya bibit penyakit dan global warming.

b. People (orang). Dalam ekonomi Islam, setiap orang dibentuk untuk melakukan kegiatan usaha ekonomi serta mensukuri hasil kerja nya dengan berdoa kepada Allah. Karena manusia hanya dapat berencana namun hanya Allah lah yang maha kuasa dan menetukan hasil dari rencana yang dibuat. Inilah yang menjadikan seorang muslim lebih percaya diri, karena ada keyakinan di dalam dirinya terhadap apa yang dilakukan, yaitu keyakinan bahwa segala perilakunya dinilai ibadah yaitu Ibadah mahdhoh yang secara langsung mendapat pahala dari sisi Allah.

c. System (Syariat). Kegiatan ekonomi yang dilakukan di muka bumi harus sesuai dengan sistem yang telah dibuat oleh Allah, yaitu manusia harus memikul amanat untuk tidak berbuat aniaya dan berbuat bodoh, ringkas nya adalah membuat kehidupan yang $m a^{\prime} r u f a t$ (kebaikan) serta mewujudkan keadilan, hal ini sebagaimana yang difirmankan Allah pada QS Al-Ahzab [33] ayat 33:

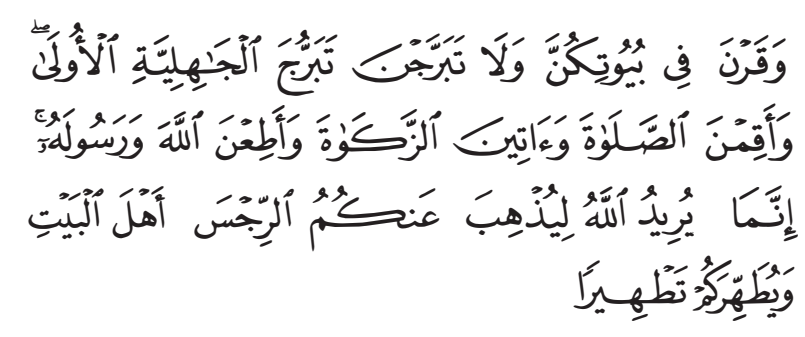

"Dan hendaklah kamu tetap di rumahmu dan janganlah kamu berhias dan bertingkah laku seperti orang-orang Jahiliyah yang dahulu dan dirikanlah shalat, tunaikanlah zakat dan ta'atilah Allah dan Rasul-Nya. Sesungguhnya Allah bermaksud hendak menghilangkan dosa dari kamu, hai ahlul bait dan membersibkan kamu sebersih-bersihnya".

Adapun fungsi dari penerapan ekonomi syariah dalam kegiatan ekonomi lebih ditujukan kepada bagaimana mewujudkan perekonomian yang solid, dengan melibatkan seluruh komponen masyarakat agar terhindar dari penyelewengan dan mendukung serta mengamalkan secara kaffah ekonomi syariah yang terbebas dari unsur riba.

Menurut Mufid, penerapan ekonomi syariah dalam aktivitas ekonomi, memiliki tiga fungsi yaitu $^{10}$ :

1. Merealisasikan pertumbuhan ekonomi dengan melibatkan seluruh komponen masyarakat.

2. Membuat rencana pembangunan ekonomi yang proaktif dan menhapuskan segala bentuk penyelewengan.

3. Menciptakan kesatuan ekonomi bagi seluruh dunia Islam guna mempersatukan negaranegara muslim.

Dari penjelasan tersebut, dapat disimpulkan bahwa pada praktek nya ekonomi Islam masih sebatas tatanan dasar, yaitu untuk mewujudkan ekonomi yang berbasis syariah dengan cara menjalankan roda ekonomi bersama-sama secara adil, memonitor pemerintahan agar tidak terjadi penyelewengan, dan mempersatukan umat Islam agar tidak terjadi disparitas antar negara muslim, sehingga negara yang kaya dapat mem-

\footnotetext{
${ }^{10}$ Moh. Mofid, Kaidah Fiqh Ekonomi Syariah: Teori dan Aplikasi Praktis, (Jakarta: ebookuid, 2017), h. 28-29
} 
bantu negara muslim yang sedang berupaya untuk memajukan perekonomian nya. Namun, konsep ekonomi Islam secara praktis masih minim dieksplorasi, hal ini menjadikan negaranegara Islam masih banyak yang melakukan dual sistem perekonomian yaitu penggabungan antara sistem ekonomi konvensional dan Islam, ekonomi yang menganut dual sistem ini tentu tidak luput dari unsur riba. Tantangan bagi para akademisi dan praktisi ialah bagaimana mengembangkan konsep ekonomi Islam agar lebih detail dan komprehensif sehingga dapat dijadikan rujukan oleh negara dalam menjalankan roda perekonomian.

\section{Implementasi Ekonomi Islam dalam Transaksi Keuangan Modern}

Wacana tentang ekonomi Islam mulai bangkit tidak hanya di tengah masyarakat Islam namun juga di dunia, antusiasme terhadap ekonomi yang berbasis syariah ini diharapkan dapat menjadi jawaban terhadap teori kapitalis dan sosialis yang telah lama ada dalam beberapa dekade yang menimbulkankan ketidak adilan antar negara, strata sosial, serta arogansi para borjuisme. Di tengah krisis ekonomi global pada tahun 2008, perbankan syariah menunjukkan performa yang tahan terhadap badai krisis keuangan, bahkan mendapat tempat yang subur di negara nonmuslim seperti Inggris, Luxemburg, Hongkong dan Singapura. Semakin menjamurnya lembaga keuangan Islam ini menunjukkan tingkat animo masyarakat dan harapan yang tinggi terhadap ekonomi Islam sebagai solusi dalam mengatasi krisis dan sebagai pengganti dari ekonomi kapitalis dan sosialis.

Tidak semua orang optimis dengan ekonomi Islam, ada juga beberapa ahli ekonomi yang mengkritisi konsep ekonomi Islam karena dirasa masih sangat jauh dari pengembangan, hal ini adalah karena keterbatasan kreatifitas para pakar ekonomi Islam dalam mengembangkan konsep ekonomi Islam yang memiliki teori perhitungan matematis dalam mengupas sistem secara teoritis dan aplikatif. Karena, konsep yang ada masih mengambil referensi dari para ulama terdahulu yang dalam penerapannya mungkin kuran relevan terhadap zaman saat ini. Oleh karena itu, teori ekonomi Islam yang ada diharapkan dapat terus dikembangkan tidak hanya dalam hal teoritis namun juga diimplementasikan dalam dunia praktis oleh masyarakat secara umum. Oleh sebab itu, kemunculan ekonomi Islam menjadi signifikan dalam memberikan kontribusi pada kegiatan bisnis di masyarakat, di bidang muamalat/ transaksi untuk merespon perubahan kehidupan sesuai dengan perubahan zaman $^{11}$.

Sebelum memahami signifikansi dari Ekonomi Islam dalam transaksi bisnis di era modern, maka perlu dipahami terlebih dahulu perbedaan antara ilmu ekonomi dan fiqh muamalat dari aspek aksiologisnya. Ilmu ekonomi mempelajari bagaimana cara untuk dapat memenuhi kebutuhan hidup, sedang fiqh muamalah lebih ke arah norma atau hukum baik yang bersifat sosial maupun komersil. Secara praktis, ilmu ekonomi menerangkan metode atau cara bagaimana transaksi bisnis dan mendapatkan keuntungan materil, sedangkan fiqh muamalah menentukan status hukum halal atau haram nya pelaksananaan transaksi bisnis ${ }^{12}$. Karena, belum tentu transaksi ekonomi tertentu adalah sah dalam pandangan fiqh muamalah, sebagai contoh, seseorang yang melakukan transaksi penjualan hasil kebun yang belum kelihatan berapa jumlah total hasil panen nya, dalam ilmu ekonomi hal ini diperbolehkan selagi penjual dan pembeli sama-sama menyetujui, namun belum tentu boleh dalam fiqh muamalah, karena mengandung hal yang gharar karena ketidak pastian dan kemungkinan wujud benda yang akan dijual, selain itu tidak ada akad yang ditentukan oleh kedua belah pihak.

Dapat disimpulkan bahwa, ilmu ekonomi Islam adalah gabungan dari ilmu ekonomi dan fiqh muamalat, yang mempelajari seluruh aktivitas ekonomi berdasarkan kaidah-kaidah

\footnotetext{
${ }^{11}$ Mardani,. Hukum Ekonomi Syariah..., h. 77

${ }^{12}$ Mardani,. Hukum Ekonomi Syariah..., h. 83
} 
fiqh dan seuai dengan tatanan ajaran agama Islam. Adapun signifikansi dari ekonomi Islam dalam bidang muamalah adalah sebagai berikut:

1. Ekonomi Islam membangun integritas muslim yang menjalankan roda ekonomi sesuai dengan ajaran Islam, dengan berpegang teguh pada keistimewaan ekonomi Islam yaitu menghindari dari segala bentuk kegiatan yang mengandung unsur riba yang dapat menyebabkan kerugian terhadap orang lain.

2. Menjadikan masyarakat terbiasa melakukan kegiatan ibadah dalam muamalah, karena kegiatan ekonomi tersebut merupakan ibadah mahdhoh yang dinilai pahala dimata Allah, sehingga tanpa terasa para produsen dan konsumen telah melakukan ibadah transaksi yang bernilai ibadah. Sebagai contoh, seseorang yang menggunakan fasilitas pada Lembaga keuangan syariah seperti Bank Syariah, Pegadaian Syariah, Baitul Mal Wattamwil, Reksana Syariah secara langsung telah menjauhkan diri nya dari perbuatan zina (zina mata), gharar, riba dan maysir. Hal ini berarti, transaksi tersebut bernilai ibadah karena telah mengamalkan dan mendukung syariat Allah Swt.

3. Mendukung upaya pemberdayaan ekonomi umat islam dan mengembangkan usahausaha kaum muslim. Ekonomi Islam tidak memperbolehkan adanya bunga dan penumpukan harta, sehingga semua keuangan harus diberdayakan ke dalam sector riil, yang menjadikan roda perekonomian tidak stagnan. Islam melarang ihtikar (penimbunan) maka setiap harta yang tidak bergerak dan tidak dimanfaatkan untuk kegiatakan ekonomi harus dikenakan pajak yang lebih besar, hal ini berguna untuk menjadikan harta tersebut dapat lebih bermanfaat. Islam juga memberikan hak kepada setiap orang untuk melakukan usaha, tanpa terbatas dengan modal dan aturan. Inilah yang membedakan Islam dengan sistem kapitalis dimana orang yang kaya akan semakin kaya karena dalam teori kapitalis, pengusaha pemula akan tersingkir dari pasar dan tidak ada rasa tolongmenolong dan rasa kasih sayang. Sedangkan dalam Islam, ummat muslim meyakini bahwa rezeki datang dari Allah, tidak perlu berupaya menyingkirkan orang lain dalam berbisnis, karena setiap manusia telah ditentukan hak dan rezeki nya sesuai dengan kadar usaha nya.

4. Mengamalkan ekonomi syariah atau ekonomi islam berarti mendukung gerakan amar máruf nahi mungkar, karena dana yang terkumpul tersebut hanya boleh dimanfaatkan untuk usaha-usaha atau proyek-proyek halal. Setiap kegiatan ekonomi Islam hanya diperbolehkan untuk digunakan dalam usaha-usaha yang sesuai dengan syariat Islam tidak boleh melakukan kegiatan yang bertentangan seperti usaha pabrik minuman keras, usaha narkoba dan narkotika, usaha perjudian, hotel yang digunakan untuk kemaksiatan atau tempat hiburan yang bernuansa mungkar seperti diskotik dan sebagainya. Penerapan ekonomi Islam ini dapat meningkatkan derajat moral masyarakat, dan memperbaiki ekonomi agar lebih tertib, sejahtera dan aman dari perbuatan mungkar sehingga tercapai baldatun thoyyibatun wa rabbun ghafur Negeri yang aman, damai dan sentosa serta mendapat ridho dan ampunan dari yang maha kuasa.

Praktik perbankan syariah yang adil, yang berbasis bagi hasil selain menguntungkan juga berhasil menggaet nasabah dengan indikasi pertumbuhannya yang sangat pesat. Selain itu, praktik sektor keuangan syariah senantiasa bersesuaian dengan sektor riil, yang pelaku utamanya adalah masyarakat menengah ke bawah. Makin besar porsi sektor keuangan syariah beroperasi, makin besar pula sektor riil yang beroperasi sehingga tidak terjadi ketimpangan antara sektor riil dan sektor moneter serta makin sempitnya jurang pemisah si kaya dan si miskin. Dengan tumbuhnya sektor riil, pertumbuhan ekonomi bisa dirasakan masyarakat secara lebih adil dan merata. ${ }^{13}$

13 Abdul, Mannan, Teori dan Praktek Ekonomi Islam, 
Selain itu, sektor syariah yang tidak bisa dianggap remeh adalah peran sosial ekonomi Islam melalui instrumen-instrumennya, seperti zakat, infak/sedekah, dan wakaf. Melalui pengelolaan yang optimal, maka zakat, infak, dan wakaf berpotensi besar mengatasi berbagai permasalahan bangsa, baik ekonomi maupun sosial.

Signifikansi ekonomi Islam pada kegiatan muamalah juga dapat dirasakan pada peran positif bank syariah dan lembaga keuangan syariah non bank yang mendorong berkembangnya sektor riil, hal ini dapat dilihat dari mulai bertambahnya porsi akad bagi hasil mudharabah dan musyarakah yang ada pada bank syariah meskipun akad murabahah masih mendominasi pada perbankan Islam ${ }^{14}$. Para pengusaha sector riil pun mulai terinspirasi dengan ekonomi syariah dan menggunakan akad dan peraturan syariah dalam bisnis mereka, sebagai contoh Hotel Syariah dan MLM Syariah, serta dorongan yang kuat dalam menggunakan produk-produk bersertifkasi halal oleh konsumen dan produsen. Jumlah para muzakki turut meningkat, menurut Public Interest Research and Advocacy Center (PIRAC) pada tahun 2007 sekitar 55\% masyarakat muslim yang menjadi reponden survey PIRAC mengakui dirinya wajib membayar zakat, yang tentunya hasil pengumpulan zakat tersebut akan dapat menaikkan taraf hidup masyarakat.

Signifikansi ekonomi Islam yang berlandaskan syariah juga dirasakan implementasinya pada usaha bank syariah yang semakin lebih banyak memiliki potensi penawaran jasa dibandingkan bank konvensional, hasil penelitian oleh Imaniyati menunjukkan bahwa implementasi akad syariah pada bank syariah yang diatur dalam UU No. 10 tahun 1998, tentang perbankan: UU 21 tahun 2008, tentang bank syariah dan peraturan bank Indonesia memberikan peluang terhadap bank syariah untuk dapat menawarkan jasa yang lebih

\footnotetext{
(Yogyakarta: Wakaf, 1993), h. 93

${ }^{14}$ Adiwarman A. Karim, Pengembangan Ekonomi Islam dan Perannya dalam Peningkatan Kesejahteraan Umat, Tarjih Vol. 9/ 2007, h. 80
}

beragam atau lebih banyak dibandingkan dengan bank konvensional ${ }^{15}$. Bahkan menurut Farida dan Nur Zulaini, implementasi syariah dalam kinerja ekonomi dapat meningkatkan keterampilan baru dan kesadaran masyarakat dalam keberadaan entitas syariah ${ }^{16}$. Ini semua menunjukkan bahwa keberadaan ekonomi syariah di tengah masyarakat selalu relevan dengan tuntutan zaman yang semakin kompleks dan variatif, dan dapat menyelesaikan turbulasi pertentangan yang terjadi di dalam praktek ekonomi dan keuangan Islam.

Publik tampaknya semakin menyadari bahwa konsep ekonomi Islam telah semakin terbuka, hal ini terbukti dengan adanya nasabah non muslim yang memilih bank syariah, bahkan beberapa pengusaha lembaga keuangan konvensional mulai melirik perbankan syariah dan membuka usaha yang syar' $i^{17}$. Interaksi dari kalangan non muslim terhadap ekonomi syariah sedikit banyak telah mengubah pola pikir dan kecurigaan yang tidak berdasar terhadap orang muslim sekaligus mengikis sikap Islamophobia. Dengan kemunculan ekonomi syariah yang semakin berkembang, menjadikan paradigma berpikir para non muslim terhadap Islam semakin berubah, kian terbuka, dan mengarah positif.

\section{Pustaka Acuan}

Chapra, M. Umer, "Masa Depan Ilmu Ekonomi Sebuah Tinjauan Islam” (terjemahan dari: The Future of Economics: An Islamic Perspective), Jakarta: Gema Insani Press, 2001

Farida dan Nur Laila Zulaini, Pengaruh Dimensi Pengembangan Pengetahuan, Peningkatan Keterampilan Baru, dan Kesadaran Masyarakat terhadap Kinerja Maqasid, Cakrawala, Vol.X, No. 1, 2015.

\footnotetext{
${ }^{15}$ Neni Sri Imaniyati, Asas dan Jenis Akad dalam Hukum Ekonomi Syariah: Implementasinya Pada Usaha Bank Syariah, Mimbar, Vol XXVII, No. 2/ 2011, h. 156

16 Farida dan Nur Laila Zulaini, Pengaruh Dimensi Pengembangan Pengetahuan, Peningkatan Keterampilan Baru, dan Kesadaran Masyarakat terhadap Kinerja Maqasid, Cakrawala, Vol.X, No. 1/ 2015, h. 20

17 Adiwarman A. karim, 2007. Pengembangan Ekonomi Islam.... h. 85
} 
Hakim, Atang Abd, Fiqh Perbankan Syariah, Bandung: Refika Aditama, 2011

Imaniyati, Neni Sri, Asas dan jenis akad dalam bukum ekonomi syariah: implementasinya pada usaha bank syariah, Mimbar, Vol XXVII, No. 2, 2011.

Karim, Adiwarman A., "Ekonomi Islam: Suatu Kajian Ekonomi Makro", Jakarta: the International Institute of Islamic Thought Indonesia, 2002

Karim, Adiwarman A., Pengembangan Ekonomi Islam dan Perannya dalam Peningkatan Kesejahteraan Umat, Tarjih Vol. 9, 2007

Mannan, Abdul, Teori dan Praktek Ekonomi Islam, Yogyakarta: Wakaf, 1993.
Mardani, Hukum Ekonomi Syariah di Indonesia. Bandung: PT Refika Aditama, 2011.

Mofid, Moh., Kaidah Fiqh Ekonomi Syariah: Teori dan Aplikasi Praktis, Jakarta: ebookuid, 2017.

Naqvi, Syed Nawab Haider, "Menggagas Ilmu Ekonomi Islam" (terjemahan dari: Islam, Economics, and Society), Yogyakarta: Pustaka Pelajar,2003.

Pusat Pengkajian dan Pengembangan Ekonomi Islam (P3EI). Ekonomi Islam. Jakarta: PT Raja Grafindo Persada, 2012.

Rahman, Afzalur. Doktrin Ekonomi Islam Jilid I. Yogyakarta: Dana Bhakti Wakaf, 1995. 